\title{
Polyamines and methyl jasmonate in bulb formation of in vitro propagated tulips
}

\author{
Małgorzata Podwyszyńska ${ }^{1} \cdot$ Ryszard Kosson $^{1} \cdot$ Jadwiga Treder $^{1}$
}

Received: 19 May 2015/ Accepted: 8 September 2015/Published online: 19 September 2015

(C) The Author(s) 2015. This article is published with open access at Springerlink.com

\begin{abstract}
Effects of polyamines (PAs), their precursors, ornithine (Orn) and arginine (Arg), as well as methyl jasmonate (MeJA) were studied on bulb formation in vitro with four tulip cultivars differing in bulbing ability. The endogenous PA profiles of the shoots and bulbing shoots were monitored during successive micropropagation stages: S1, sixth week of the standard multiplication subculture; S2, fifth week of the last multiplication subculture; $\mathrm{S} 3,5$ weeks later, just before the cold treatment; S4, at the end of the 13-week-cold treatment; and S5, 6 weeks after the end of cold treatment (shoot base swelling/bulb formation phase). Putrescine (Put), spermidine (Spd) and spermine $(\mathrm{Spm})(50$ and $100 \mu \mathrm{M})$ as well as Arg and Orn (500 and $1000 \mu \mathrm{M}$ ) were added to the medium at various bulbing stages (S3, S4 and S5). Positive effects of these compounds on bulb formation were found for the cultivar 'New Beet' (NB), with the lowest bulbing ability. Both PAs and their precursors, when used at lower concentrations at the beginning of bulbing process (S3), together with standard MeJA treatment, significantly enhanced bulb numbers in this cultivar. Putrescine was the major endogenous polyamine at the stages of shoot multiplication (S1-S2). Spd levels were the highest in 'Fringed Black' (FB), the cultivar of extremely high bulbing ability, and this PA dominated over Put during the entire micropropagation process in this cultivar. Endogenous Spd contents manifested similar dynamics in all cultivars showing two peaks: at shoot multiplication (S2) and at the end of cooling (S4). The contents of all the PAs were the lowest at the
\end{abstract}

Małgorzata Podwyszyńska

malgorzata.podwyszynska@inhort.pl

1 Research Institute of Horticulture, Konstytucji 3 Maja, 96-100 Skierniewice, Poland final bulbing stage (S5) except the Spm level in cultivar NB in which it increased at this time. It is postulated that the high bulbing competence may be related to a transient increase in Spd content in response to low temperature treatment (S4), followed by its rapid decrease during bulb growth and maturation (S5, 6 weeks after the end of cooling) when developing bulbs begin to enter dormancy. The low levels of all the PAs at final bulbing stage as well as low Put/Spd ratio may also aid in the bulb formation of tulip in vitro.

Keywords Tulipa Polyamines - MeJA .

Micropropagation $\cdot$ Bulb formation $\cdot$ In vitro

\section{Introduction}

In the majority of geophyte species, the formation of bulbs, corms or tubers is an essential stage in the micropropagation process because only the storage organ shows high rooting ability and good field performance as, e.g. in lily (Langens-Gerrits et al. 2003; Ishimori et al. 2007; Ascough et al. 2008) and tulip (Podwyszyńska and Sochacki 2010). In our tulip micropropagation system, the bulbing process is directly induced in shoots multiplied in vitro during several cycles over the course of 1-3 years (Podwyszyńska and Sochacki 2010). Bulb development takes 8-10 months and comprises three phases. In the first phase, shoots are prepared for bulbing at the temperature of $18{ }^{\circ} \mathrm{C}$. They develop dormancy and become sensitive to low temperature treatment, and their endogenous level of abscisic acid (ABA) increases and level of indole-3-acetic acid (IAA) decreases (Podwyszyńska et al. 2004). In the second phase, bulb development is induced by treatment of the shoots with a low temperature of $5{ }^{\circ} \mathrm{C}$ for $12-14$ weeks. During 
this phase, shoot dormancy is released, endogenous ABA levels fall while IAA levels rise. In the third phase, which takes 2-3 months, shoots are maintained on sucrose-rich medium at $18{ }^{\circ} \mathrm{C}$ and bulbs form.

Under this sequence of treatments, shoots of most tulip genotypes produce bulbs successfully. However, some genotypes have low bulbing capacity under these conditions (Podwyszyńska 2006b; Podwyszyńska et al. 2014). Other tulip genotypes, such as the one used for this study, the breeding line P14, produce high numbers of very small bulbs with an average mass below $60 \mathrm{mg}$. Such small bulbs grown in soil emerge and form new daughter bulbs only in about $30 \%$ of cases. In turn, another tulip genotype "New Beet" (NB) forms relatively large bulbs in vitro but with a low efficiency of $50 \%$.

Therefore, several attempts have been undertaken in order to improve bulb formation of in vitro cultured tulip. It was found that modification and prolongation to 14 weeks of the last multiplication subculture, prior to cooling combined with the application of NAA and gibberellin biosynthesis inhibitors, enhance shoot's bulbing capacity (Podwyszyńska 2006b). Bulbing efficiency was markedly increased by treatments with MeJA at the last phase of this process, 6 weeks after the end of cooling shoots (Podwyszyńska 2006a). Recently, it has been proved that the replacement of thidiazuron (TDZ) (used as standard for shoot multiplication) with isopentenyladenine (iP) in the last multiplication subculture significantly enhanced bulb formation (Podwyszyńska et al. 2014). In the case of the cultivar NB, with low bulbing ability, such treatments, however, were found to be insufficient for enhancing the efficiency of this storage organ development.

For a better understanding of the mechanism of bulb formation, hormonal status was analysed in successive stages of this process for many bulbous species, both in natural and in vitro conditions. The important role of decreasing endogenous GAs during the bulb induction phase was shown in Allium wakegi (Yamazaki et al. 2002). Their findings clarify why gibberellin inhibitors stimulated bulb formation of micropropagated lily (Kim et al. 1994) and tulip (Podwyszyńska 2006b). The role of ABA level in dormancy development (increasing level) and release (decreasing level) closely associated with an in vitro bulb formation was studied in lily (Gerrits et al. 1992; Kim et al. 1994), tulip (Podwyszynska et al. 2004) and onion (Yamazaki et al. 2002). Also, jasmonates, jasmonic acid (JA) and methyl jasmonate (MeJA) have been considered to play an important role in the process of storage organ formation, including bulb formation in vitro of Allium sativum and A. cepa (Ravnikar et al. 1993; Koda 1997; Kim et al. 2003), Tulipa gesneriana (Podwyszyńska 2006b) and Narcissus triandus (Santos and Salema 2000).
However, little attention has been paid to the action of polyamines (PAs) in bulb formation. First, their role was studied in the development of tubers in potato (Mader 1995; Kumar et al. 1996). Recently, their beneficial effects have been reported for the in vitro formation of gladiolus corms (Kumar et al. 2011; Kumar and Palni 2013) and yam tubers (Ondo Ovono et al. 2010a, b). Polyamines (PAs): putrescine (Put), spermidine (Spd) and spermine (Spm) occur ubiquitously in plants, especially in actively growing tissues, and are considered plant growth regulators influencing several physiological and developmental processes (Kakkar et al. 2000; Bais and Ravishankar 2002; KaurSawhney et al. 2003; Kosson and Prange 2005; Hussain et al. 2011; Anwar et al. 2015). They are involved in cell division, somatic embryogenesis, stem elongation and flowering, root growth, tuber development, senescence and plant responses to abiotic and biotic stress tolerance. However, the mechanism of action remains to be elucidated. PAs are compounds with amino groups. The amino acids (AA) arginine (Arg) and ornithine (Orn) are precursors of putrescine. Spermidine is synthesised from putrescine and spermine from spermidine with S-adenosylmethionine in the presence of the spermine synthase. There is little information on polyamine action in the process of in vivo bulb formation in tulip (Le Nard and Fiala 1990; Kollöffel et al. 1992). So far the role of polyamines was not studied in tulip cultured in vitro.

In recent years importance of methyl jasmonates in polyamine metabolism has been investigated, and many studies indicate that application of methyl jasmonates can alter polyamine metabolism, resulting in accumulating of polyamines in tissue. This effect is attributed to influencing gene expression resulting in changes in activity of polyamine biosynthesis genes: arginine decarboxylase (ADC), ornithine decarboxylase (ODC) and S-adenosylmethionine decarboxylase (SAMDC) (Walters et al. 2002).

The aim of this study was to determine the effects of polyamines, their precursors and methyl jasmonate on the efficiency of in vitro bulb formation in tulip. Analysis of the endogenous levels of polyamines during this process was also included.

\section{Materials and methods}

\section{Plant material and micropropagation conditions}

Four tulip genotypes differing considerably in capacity of in vitro bulb formation were used in the study: 'Fringed Black' (FB) (late flowering Fringed Group) with extremely high bulbing ability, in which shoots form some bulbs even without low temperature treatment; P20 (mead-season 
flowering, Fringed Group) forming bulbs with relatively high efficiency; 'New Beet' (NB) (Single Late Group) with the lowest ability to form bulbs; and P14 (late flowering, Lily-flowered Group) forming numerous but very small bulbs. In vitro shoot cultures of these cultivars were established, multiplied by adventitious regeneration, and prepared for bulb formation, essentially following our previously published protocol (Podwyszyńska and Sochacki 2010), except when polyamines, amino acids and MeJA were added in the particular experiments. Briefly, at $\mathrm{S} 1$ the shoots were continuously multiplied in vitro with 6 week subculture periods in $330 \mathrm{ml}$ jars containing $40 \mathrm{ml}$ of multiplication medium (Podwyszyńska and Sochacki 2010) supplemented with $1 \mu \mathrm{M}$ TDZ, $20 \mu \mathrm{M}$ iP and $1 \mu \mathrm{M}$ NAA solidified with $6 \mathrm{~g} \mathrm{l}^{-1}$ agar (Difco). In the last multiplication subculture, iP was added at $25 \mu \mathrm{M}$ but no TDZ. After 5 weeks of this last multiplication subculture (S2), a liquid medium (35 ml per jar) was added containing Murashige and Skoog (1962) (MS) mineral and organic compounds and $5 \mu \mathrm{M}$ paclobutrazol, and the shoots were grown on the resulting two-phase medium for a further 5 weeks (S3) (thus the last subculture period before cooling was prolonged to 10 weeks). Then, the shoots were transferred in undivided clusters to modified MS medium ( $60 \mathrm{ml}$ per jar) containing ammonium nitrate at the concentration reduced to the half, $7 \%$ sucrose and $0.1 \%$ activated charcoal but no cytokinins, auxins nor paclobutrazol and the jars were kept at $5{ }^{\circ} \mathrm{C}$ for 13 weeks to induce the bulbing process. Finally (after the end of cooling, S4), to initiate bulb growth, the shoots were cultured (on the same medium) for 13 weeks at $16{ }^{\circ} \mathrm{C}$ with $16 / 8 \mathrm{~h}$ photoperiods (illuminated at a photosynthetic photon flux density of $55 \mu \mathrm{mol} \mathrm{m}{ }^{-2} \mathrm{~s}^{-1}$ by warm-white fluorescent lamps during the light phases). Shoot base swelling, i.e. bulb development start approximately 6 weeks after the end of cooling (S5). In order to accelerate bulb formation, except when mentioned, MeJA (Duchefa Biochemie BV, The Netherlands) solution was added twice: seven and ten weeks after the end of cooling. MeJA solution was added under the sterile conditions $(5 \mathrm{~mL}$ of $0.1 \%$ MeJA solution per $100 \mathrm{~mL}$ of a culture medium) (Podwyszyńska and Sochacki 2010). A solution of $0.1 \%$ MeJA was dissolved (v/v) in $10 \%$ ethanol.

In order to evaluate the effects of PAs and their precursors on bulb formation, four experiments were performed in which these compounds were added to the medium (before autoclaving) at different stages. The interactions of PAs and AAs with MeJA were also estimated in the cultivars NB and P14, when stated.

\section{Experiment 1}

The aim of this experiment was to determine the effect of MeJA and its interaction with PAs (Put and Spm at
$100 \mu \mathrm{M}$ ) and AAs (Arg and Orn $1000 \mu \mathrm{M}$ ) on bulb formation of the cultivar NB (of the lowest bulbing ability). The compounds were added to the bulbing medium (without PGRs and with $7 \%$ sucrose) just before cooling (S3). MeJA solution was added two times: 7 and 10 weeks after the end of cooling (as described above) to the half of the containers with bulbing shoots.

\section{Experiment 2}

All four tulip cultivars were used and PAs (Put and Spm) and AAs (Arg and Orn) were added to the bulbing medium just before cooling (S3). The concentrations of PAs and AAs were selected based on the preliminary experiment. Arg and Orn were used at 500 and $1000 \mu \mathrm{M}$, and Put and Spm at 50 and $100 \mu \mathrm{M}$. MeJA solution was added two times, as in the standard procedure described above.

\section{Experiment 3}

The genotypes NB and P14 were used. PAs, Put, Spm and Spd, as well as Arg and Orn, were added in water solutions to the shoot cultures just after the end of cooling (S4). The compounds were added in sterile water solutions in the way that the final concentration of each polyamine was $50 \mu \mathrm{M}$ and concentration of each amino acid was $500 \mu \mathrm{M}$. MeJA effects, depending on PA/AA treatments, were studied only for the cultivar NB. MeJA was added (as in standard procedure) to the half of the NB bulbing shoot cultures of each AA/PA treatment.

\section{Experiment 4}

The genotypes NB and P14 were used. PAs (Put, Spm and Spd) as well as AAs (Arg and Orn) were added in water solutions to bulbing shoot cultures 6 weeks after the end of cooling (S5). The compounds were added in the same way as in the third experiment: PAs at the final concentration in the medium of $50 \mu \mathrm{M}$ and AAs at $500 \mu \mathrm{M}$. MeJA was added (as in standard procedure) to the half of the containers with bulbing shoots treated with AA/PA treatments.

Control shoot cultures were not treated with either PAs or AAs.

Thirteen weeks after the end of cooling (in each experiment), bulbs were taken out of containers, rinsed with tap water, dried and stored at $20{ }^{\circ} \mathrm{C}$ for 5 weeks. At this time, the total number of bulbs and the number of regular bulbs (properly formed and covered with tunic) obtained from each jar as well as mean bulb mass were recorded. Five or six jars, each containing three clumps of 3-4 shoots (10 shoots per jar), were used in the in vitro bulb formation efficiency experiments. The bulb 
formation data were subjected to analysis of variance and treatment means were compared by Duncan's test at $P=0.05$.

\section{Determination of polyamines}

The endogenous polyamine profiles were monitored by the following sampling, extraction and high-performance liquid chromatography HPLC procedures. Samples of basal parts of shoots (ca. $1 \mathrm{~cm}$ long and $1 \mathrm{~g}$ fresh weight) were taken at the following stages of micropropagation/bulb development: S1, after 6 weeks of the standard multiplication subculture; $\mathrm{S} 2$, at the fifth week of the last multiplication subculture; S3, 5 weeks after the addition of liquid medium containing paclobutrazol (just before the cold treatment); S4, after 13 weeks (the end) of cold treatment; and S5, 6 weeks after the end of cold treatment (during the shoot base swelling/bulb formation phase. The samples were frozen at $-20{ }^{\circ} \mathrm{C}$, lyophilised and stored at $-20{ }^{\circ} \mathrm{C}$ until analyses.

Tissue contents of PAs were also compared during the last two bulbing stages (S4 and S5) between two cultivars that were markedly differing in bulbing ability (easily forming bulbs cultivar FB and recalcitrant cultivar NB) depending on exogenous AA (Arg and Orn each at $500 \mu \mathrm{M}$ ) and PA (Put and Spm, each at $50 \mu \mathrm{M}$ ) treatments given before cooling (S3).

Four samples containing plant material were collected from four jars (one mixed sample from one jar) representing each treatment. Free polyamines were analysed according to basic procedure of Flores and Galston (1982) with some later modifications (Kosson and Elkner 2010; Horbowicz et al. 2011).

Briefly, plant tissues were homogenised in $5 \%(\mathrm{v} / \mathrm{v})$ perchloric acid and amines were derivatised with benzoyl chloride. Bonzoyl derivatives of amines were extracted with ethyl acetate and pooled acetate fractions were evaporated to dryness at $40{ }^{\circ} \mathrm{C}$ in stream of air. The residue was dissolved in mobile phase used for HPLC analyses. HPLC analysis was performed with a liquid chromatograph (Agilent Technologies, model 1200 Series). The mobile phase was a mixture of acetonitrile-water $(45: 55, \mathrm{v} / \mathrm{v})$ at a flow rate of $1.0 \mathrm{~mL} \mathrm{~min}{ }^{-1}$. Benzoylated amines were eluted isocratically at $30{ }^{\circ} \mathrm{C}$ using an RP column Eclipse $\mathrm{XDB}-\mathrm{C}_{18}$ analytical $(4.6 \times 150 \mathrm{~mm}, 5 \mu \mathrm{m}$ particle size $)$ and $\mathrm{C}_{18}$ guard column. The benzoyl polyamines were detected at $245 \mathrm{~nm}$, DAD detector, and amines contents were calculated from standard curves of commercially available polyamines.

Data were subjected to analysis of variance and treatment means were compared by Duncan's test at $P=0.05$.

\section{Results}

\section{Bulb formation}

The studied PAs and their precursors significantly influenced bulb formation of micropropagated tulips but their effects were strongly differentiated depending on genotype, term of treatment and MeJA application.

In the cultivars easily forming bulbs (FB, P20 and P14), the commencement of bulb enlargement started approximately 6 weeks after the end of cooling and was associated with leaf yellowing. In NB, such symptoms occurred 4 weeks later than in other cultivars and leaf yellowing was visible, even later, about 12-13 weeks after cooling (Fig. 1a).

Results of the first experiment with the cultivar NB and PAs/AAs application before cooling (S3) showed that MeJA did not influence bulb numbers and decreased the bulb mass of control shoots (Table 1). Instead, Put and Spm $(100 \mu \mathrm{M})$ combined with MeJA treatment significantly enhanced total and regular bulb numbers (Fig. 1b). Regular bulb numbers increased from 7.2 observed in control to ca. 10.5 for Put and Spm treatments.

Results of the second experiment conducted with all four cultivars, in which AAs and PAs were added to the medium before cooling (S3) and standard MeJA treatment was applied, are presented in Table 2. In cultivar NB, all of the studied PAs and AAs markedly enhanced the total bulb number compared to control (9.4). The highest total bulb numbers (21.0-23.8) were noted with ornithine, arginine and putrescine used at lower concentrations. In this cultivar, the numbers of regular bulbs were also ca. twofold higher for Orn and Arg (12.5 and 11.0, respectively) applied at low concentrations compared to control. In the cultivar NB, the mean bulb mass was enhanced significantly (by ca. $36 \%$ ) by the application of spermine at $100 \mu \mathrm{M}$. In cultivar $\mathrm{FB}$, only ornithine at $1000 \mu \mathrm{M}$ increased significantly mean bulb mass $(584.9 \mathrm{mg})$ by ca $57 \%$ compared to control. In the cultivar P14 producing numerous small bulbs, AAs and PAs applied at lower concentrations did not influence bulb formation, except for ornithine, which considerably enhanced the total bulb number. Instead, the addition of AAs or PAs at higher concentrations significantly decreased both bulb numbers and mean bulb mass. In cultivar P20, these compounds generally did not have any positive effect on bulb formation. Arg at $500 \mu \mathrm{M}$ and Put at $50 \mu \mathrm{M}$ significantly reduced the number of regular bulbs to the half compared to the control.

The results of the third experiment, in which the cultivars NB and P14 were used and PA/AA were applied just after the end of cooling (S4), confirmed that MeJA 

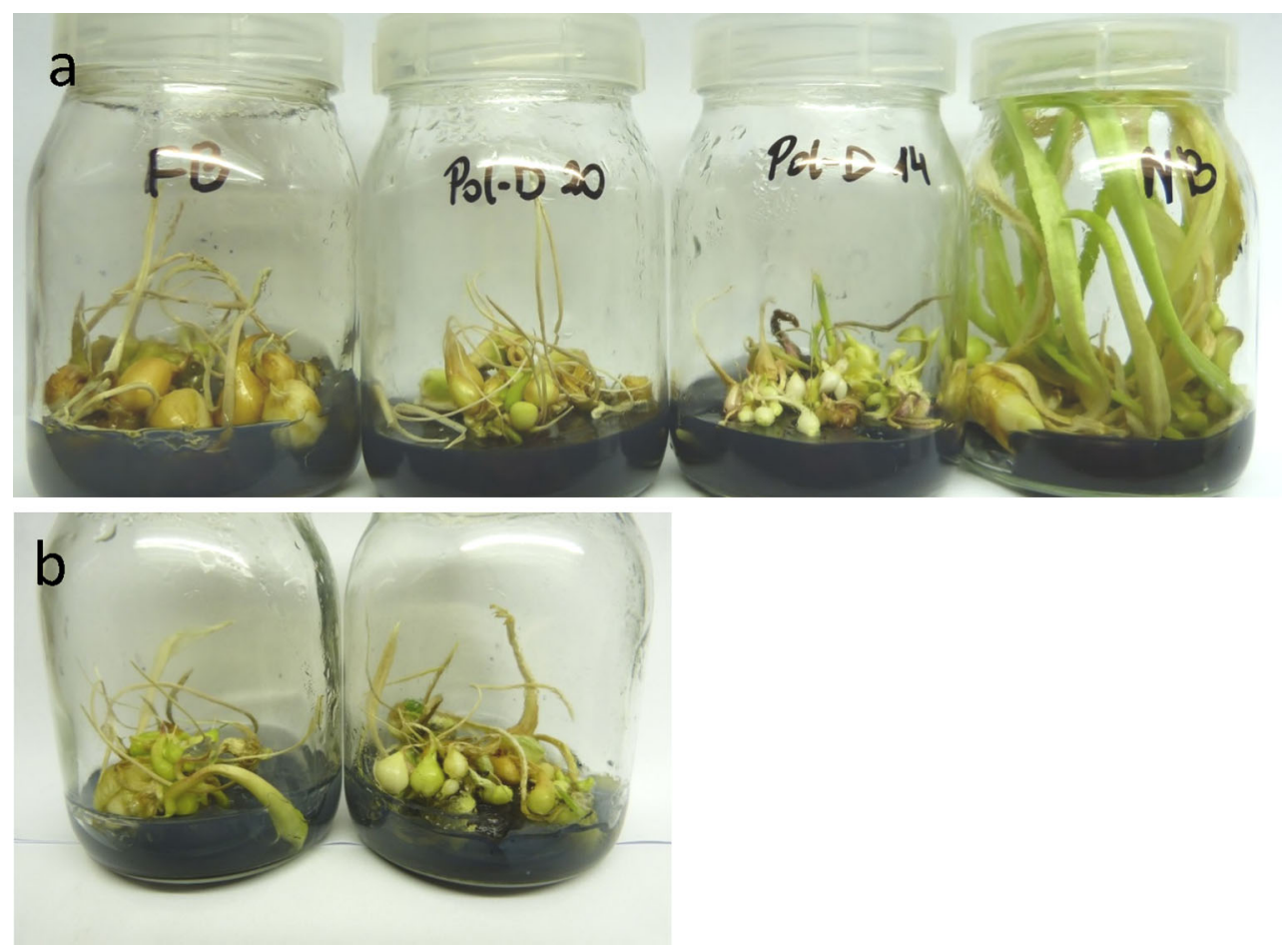

Fig. 1 Differences among micropropagated tulip cultivars in bulbing ability. a Bulbs/bulbing shoots 9 weeks after the end of low temperature treatment cultured on a control bulbing medium with standard MeJA treatment; from the left 'Fringed Black' of extremely high bulbing ability (bulb formation process finished), P20 - high ability (bulb formation finished), P14-producing numerous small

generally decreased bulb numbers, except when applied for the Orn treated shoots (Table 3). In this treatment, the highest total number (21.8) and regular bulb number (18.0) were obtained that differed significantly from the control MeJA+ (13.8 and 12.5, respectively), but were similar to the control MeJA-. The application of Orn, Arg, Put and $\mathrm{Spm}$ at $\mathrm{S} 4$ without MeJA treatment caused a significant increase of NB bulb mass to ca. 298-332 mg from ca. $200 \mathrm{mg}$, which was observed in control MeJA-. MeJA treatment, in general, slightly enhanced the bulb mass compared to PA/AA treatments without MeJA application. At the same time, bulb mass (306.4 and 328.5) obtained at MeJA treatment combined with Orn and Spm was significantly higher compared to control MeJA-. In the cultivar P14 (shoots untreated with MeJA), the application of Orn, Put and Spd at S4 caused a marked increase in bulb numbers (Fig. 2).

In the fourth experiment, the cultivars NB and $\mathrm{P} 14$ were used and AAs/PAs were applied to the shoot cultures 6 weeks after the end of cooling (S5) and the effects of these compounds on bulb formation were studied depending on MeJA treatment (Table 4). In the cultivar NB, MeJA generally decreased bulb numbers. In P14 shoot cultures treated with Arg or Put, MeJA application also bulbs (bulb are formed but not yet covered with tunics) and 'New Beet'-delayed and occasionally bulbing (leaves without senescence symptoms). b Bulbing shoots/bulbs of 'New Beet' 13 weeks after the end of low temperature treatment with standard MeJA treatment, cultured on a control bulbing medium (left) and with $\operatorname{Spm}(50 \mu \mathrm{M})$ (right) added to the medium before cooling, at S3

significantly decreased the total number of bulbs. In this cultivar, however, MeJA combined with Arg resulted with the highest number (9.5) of regular bulbs larger than $100 \mathrm{mg}$ and the highest mean bulb mass $(80.4 \mathrm{mg}$ ). Besides, both of these values differed significantly from the control MeJA+ (6.8 bulbs of $53.7 \mathrm{mg}$ mean bulb mass, respectively). Orn at $500 \mu \mathrm{M}$ combined with $\mathrm{MeJA}$ also enhanced bulb mass $(75.1 \mathrm{mg})$ in P14 shoots compared to the control MeJA+.

\section{Endogenous polyamine contents}

\section{Polyamine patterns and dynamics}

during the micropropagation process depending on genotype

In standard culture conditions (control medium), significant differences in endogenous PA levels and patterns were noted between genotypes and developmental phases.

Putrescine was generally the most abundant polyamine in three cultivars, NB, P14 and P20 (Fig. 3a). In the cultivar NB, with the lowest bulbing capacity, Put levels were extremely high (1177.9 and $1700.9 \mathrm{nmol} \mathrm{g}^{-1} \mathrm{FM}$ ) at S1 (shoot multiplication stage) and S2 (5th week of the last 
Table 1 Bulb formation in vitro of the tulip cultivar NB following treatments with polyamines and amino acids given before low temperature treatment (S3) depending on MeJA treatment; data recorded 13 weeks after the end of cooling; probability value $(P)$ of $F$ test from two-factor analysis of variance of the bulb formation parameters

\begin{tabular}{lll}
\hline Treatment $(\mu \mathrm{M})$ & \multicolumn{1}{l}{ MeJA } \\
\cline { 2 - 3 } & $(-)$ & $(+)$ \\
\hline Total bulb number & & \\
Control & $14.6 \pm 3.97 \mathrm{bc}^{*}$ & $14.8 \pm 3.42 \mathrm{bc}$ \\
Ornithine 1000 & $16.2 \pm 2.59 \mathrm{abc}$ & $18.8 \pm 5.93 \mathrm{abc}$ \\
Arginine 1000 & $14.2 \pm 3.35 \mathrm{bc}$ & $19.2 \pm 3.56 \mathrm{ab}$ \\
Putrescine 100 & $13.6 \pm 3.58 \mathrm{c}$ & $20.2 \pm 2.59 \mathrm{a}$ \\
Spermine 100 & $18.3 \pm 4.03 \mathrm{abc}$ & $20.8 \pm 4.03 \mathrm{a}$
\end{tabular}

\begin{tabular}{lll}
\hline Effect & $P$ \\
\hline AA/polyamines & 0.09 & \\
MeJA $(-/+)$ & $0.00^{* *}$ & \\
AA/polyamines $\times$ MeJA (-/+) & 0.36 & \\
Regular bulb number & & \\
Control & $8.6 \pm 1.82 \mathrm{abc}$ & $7.2 \pm 2.28 \mathrm{bc}$ \\
Ornithine 1000 & $9.4 \pm 2.01 \mathrm{ab}$ & $7.0 \pm 1.22 \mathrm{bc}$ \\
Arginine 1000 & $7.8 \pm 1.30 \mathrm{bc}$ & $9.2 \pm 2.49 \mathrm{abc}$ \\
Putrescine 100 & $6.6 \pm 1.95 \mathrm{c}$ & $10.4 \pm 1.67 \mathrm{a}$ \\
Spermine 100 & $8.8 \pm 0.96 \mathrm{abc}$ & $10.5 \pm 1.73 \mathrm{a}$
\end{tabular}

\begin{tabular}{lll}
\hline Effect & $P$ \\
\hline AA/polyamines & 0.27 & \\
MeJA $(-/+)$ & 0.22 & \\
AA/polyamines $\times$ MeJA & 0.00 & \\
$\quad(-/+)$ & & \\
Mean bulb mass $(m g)$ & & \\
Control & $645.8 \pm 184.2 \mathrm{a}$ & $430.2 \pm 103.0 \mathrm{~b}$ \\
Ornithine 1000 & $533.7 \pm 102.8 \mathrm{ab}$ & $454.0 \pm 105.2 \mathrm{~b}$ \\
Arginine 1000 & $509.3 \pm 101.3 \mathrm{ab}$ & $483.3 \pm 89.5 \mathrm{~b}$ \\
Putrescine 100 & $524.4 \pm 74.3 \mathrm{ab}$ & $443.5 \pm 102.8 \mathrm{~b}$ \\
Spermine 100 & $430.7 \pm 127.7 \mathrm{~b}$ & $474.8 \pm 79.8 \mathrm{~b}$
\end{tabular}

\begin{tabular}{ll}
\hline Effect & $P$ \\
\hline AA/polyamines & 0.50 \\
MeJA $(-/+)$ & 0.00 \\
AA/polyamines $\times$ & 0.12 \\
MeJA $(-/+)$ &
\end{tabular}

* Mean separation within each parameter of growth by Duncan's multiple range test. The mean $\pm \mathrm{SD}(\mathrm{n}=5)$ followed by the same letter do not differ at $P=0.05$

** $P$ value in italic means that effect is significant

multiplication subculture), respectively. A relatively high Put level at $\mathrm{S} 1$ (ca. $580 \mathrm{nmol} \mathrm{g}^{-1} \mathrm{FM}$ ) was also noted for the cultivar P14. At S1, the Put content in NB was 14.6fold higher than in FB (ca. $116 \mathrm{nmol} \mathrm{g}^{-1} \mathrm{FM}$ ). Then, at S3 (just before cooling), Put level significantly decreased in
NB by ca. $70 \%$ and was the lowest $\left(51.5 \mathrm{nmol} \mathrm{g}^{-1} \mathrm{FM}\right)$ at the final bulbing stage, S5 (6 weeks after the end of cooling). In general, Put levels decreased progressively in three cultivars, NB, P14 and P20 in successive phases of bulb formation (S2-S5) and were the lowest at S5. In contrast, Put levels in FB were very low and stable during the entire period of the bulbing process with the higher level of ca. $115 \mathrm{nmol} \mathrm{g}^{-1} \mathrm{FM}$ at shoot multiplication stages ( $\mathrm{S} 1$ and S2) and the lowest level of $45.7 \mathrm{nmol} \mathrm{g}^{-1} \mathrm{FM}$ at S4 (just after the end of cooling).

Spermidine highest levels (ranging from ca. 169 to $397 \mathrm{nmol} \mathrm{g}^{-1} \mathrm{FM}$ ) were observed in P-14 (the cultivar producing numerous but small bulbs), whereas the lowest levels (from 63.4 to $115.1 \mathrm{nmol} \mathrm{g}^{-1} \mathrm{FM}$ ) were found in the cultivar P20, with high bulbing ability. In other genotypes, $\mathrm{FB}$ and $\mathrm{NB}$, the levels of this compound were slightly lower than in P14 (Fig. 3b). The trends in Spd dynamics were generally similar in all of the genotypes. In P14 at S1 (the shoot multiplication stage), Spd content was $330 \mathrm{nmol} \mathrm{g}^{-1} \mathrm{FM}$. Then, it rose to $389 \mathrm{nmol} \mathrm{g}^{-1} \mathrm{FM}$ at S2 (fifth week of the last multiplication subculture) and declined again to $288 \mathrm{nmol} \mathrm{g}^{-1} \mathrm{FM}$ at S3 (just before cooling). At S4 (just after the end of cooling), Spd content reached the highest value ( $\left.397 \mathrm{nmol} \mathrm{g}^{-1} \mathrm{FM}\right)$ to reduce to the lowest content six weeks later (S5) (ca. $170 \mathrm{nmol} \mathrm{g}^{-1}$ ).

Spermine levels and dynamics differ significantly between genotypes. In general, this polyamine occurred at the lowest concentrations compared to the endogenous contents of Put and Spd. The highest levels (96 and $86 \mathrm{nmol} \mathrm{g}^{-1}$ ) were noted in P14 at S2 and FB at S3, respectively (Fig. 3c). Similar trends in Spm dynamics were observed for the cultivars P14, P-20 and NB during the stages S1-S4. The contents increased slightly from S1 to S2, and then lowered at S3 (before cooling). During the cooling period, the levels in these three cultivars did not change significantly. Subsequently, between S4 and S5, the contents declined drastically in P14 and FB from ca $72 \mathrm{nmol} \mathrm{g}^{-1}$ to ca. $20 \mathrm{nmol} \mathrm{g}^{-1} \mathrm{FM}$ but in NB increased. In genotype P20, Spm contents (13.8-28.7 $\mathrm{nmol} \mathrm{g}^{-1} \mathrm{FM}$ ) were very low and generally stable through the micropropagation stages.

\section{Putrescine to spermidine ratio}

The high predominance of Put, especially at shoot multiplication stages, was observed both in the cultivar with low bulbing ability, NB, and easily forming bulbs, P20 (Table 5); Put/Spd ratios ranged from 4.67 to 5.0. In contrast, Spd dominated in the cultivar FB of extremely high bulbing ability in which Put/Spd ratio was during all the phases below 1. Put/Spd ratios of all the cultivars were the high during multiplication stages, S1 and S2. Subsequently, when shoots enter dormancy at S3 (before cooling), Put/Spd ratios decreased markedly and continued to decrease in subsequent 
Table 2 Bulb formation in vitro in four tulip cultivars depending on exogenous polyamines and their precursors added to a medium before low temperature treatment (S3); all bulbing shoots were treated with MeJA; data recorded 13 weeks after the end of cooling; probability value $(P)$ of $F$ test from one way-analysis of variance of the bulb formation parameters

\begin{tabular}{|c|c|c|c|c|}
\hline \multirow[t]{2}{*}{ Treatment $(\mu \mathrm{M})$} & \multicolumn{4}{|l|}{ Genotype } \\
\hline & NB & FB & Pol-14 & Pol-20 \\
\hline \multicolumn{5}{|c|}{ Total bulb number } \\
\hline Control & $9.4 \pm 2.97 \mathrm{e}^{*}$ & $13.3 \pm 1.26 \mathrm{ab}$ & $25.8 \pm 5.32 b$ & $25.0 \pm 2.45 \mathrm{ab}$ \\
\hline Ornithyne 500 & $21.0 \pm 5.10 \mathrm{abc}$ & $10.7 \pm 3.08 \mathrm{bc}$ & $34.0 \pm 4.71 \mathrm{a}$ & $20.5 \pm 4.12 \mathrm{abcd}$ \\
\hline Ornithyne 1000 & $16.0 \pm 4.47 \mathrm{~cd}$ & $10.5 \pm 4.28 \mathrm{bc}$ & $8.3 \pm 1.26 \mathrm{e}$ & $18.5 \pm 3.87 \mathrm{~cd}$ \\
\hline Arginine 500 & $22.8 \pm 6.46 \mathrm{ab}$ & $11.8 \pm 3.13 \mathrm{ab}$ & $23.4 \pm 4.45 \mathrm{bc}$ & $19.3 \pm 3.77 \mathrm{bcd}$ \\
\hline Arginine 1000 & $17.8 \pm 2.77 \mathrm{abcd}$ & $12.0 \pm 0.82 \mathrm{ab}$ & $17.0 \pm 4.76 \mathrm{~d}$ & $20.0 \pm 3.65 \mathrm{bcd}$ \\
\hline Putrescine 50 & $23.8 \pm 5.85 \mathrm{a}$ & $11.2 \pm 2.86 \mathrm{bc}$ & $21.8 \pm 3.95 \mathrm{~cd}$ & $15.0 \pm 2.00 \mathrm{~d}$ \\
\hline Putrescine 100 & $16.7 \pm 5.50 \mathrm{bcd}$ & $15.8 \pm 3.20 \mathrm{a}$ & $15.5 \pm 4.20 \mathrm{~d}$ & $25.8 \pm 4.21 \mathrm{a}$ \\
\hline Spermine 50 & $16.2 \pm 5.15 \mathrm{~cd}$ & $10.3 \pm 1.97 \mathrm{bc}$ & $23.3 \pm 4.92 \mathrm{bc}$ & $24.0 \pm 4.69 a b c$ \\
\hline Spermine 100 & $13.7 \pm 2.25 \mathrm{de}$ & $14.3 \pm 3.30 \mathrm{ab}$ & $20.3 \pm 6.55 \mathrm{bcd}$ & $26.0 \pm 4.97 \mathrm{a}$ \\
\hline Effect & $P=0.00 * *$ & $P=0.11$ & $P=0.00$ & $P=0.00$ \\
\hline \multicolumn{5}{|c|}{ Regular bulb number } \\
\hline Control & $6.8 \pm 1.79 \mathrm{c}$ & $10.0 \pm 3.16 \mathrm{ab}$ & $18.5 \pm 2.89 \mathrm{a}$ & $18.0 \pm 2.16 \mathrm{ab}$ \\
\hline Ornithyne 500 & $12.5 \pm 1.91 \mathrm{a}$ & $8.8 \pm 2.48 \mathrm{~b}$ & $19.0 \pm 4.69 \mathrm{a}$ & $13.0 \pm 6.38 \mathrm{bcd}$ \\
\hline Ornithyne 1000 & $8.0 \pm 2.83 \mathrm{c}$ & $9.5 \pm 3.78 \mathrm{ab}$ & $4.0 \pm 2.16 \mathrm{e}$ & $14.0 \pm 2.94 \mathrm{bcd}$ \\
\hline Arginine 500 & $11.0 \pm 4.24 \mathrm{ab}$ & $7.8 \pm 2.56 \mathrm{~b}$ & $13.6 \pm 3.65 \mathrm{a}-\mathrm{d}$ & $11.3 \pm 3.30 \mathrm{~cd}$ \\
\hline Arginine 1000 & $6.4 \pm 3.05 \mathrm{c}$ & $10.0 \pm 2.94 \mathrm{ab}$ & $8.5 \pm 2.08 \mathrm{de}$ & $14.5 \pm 2.38 \mathrm{abcd}$ \\
\hline Putrescine 50 & $7.7 \pm 2.50 \mathrm{c}$ & $9.3 \pm 3.39 \mathrm{ab}$ & $14.5 \pm 4.93 \mathrm{abc}$ & $9.5 \pm 1.00 \mathrm{~d}$ \\
\hline Putrescine 100 & $9.0 \pm 2.45 \mathrm{bc}$ & $12.3 \pm 2.99 \mathrm{a}$ & $9.3 \pm 3.40 \mathrm{~cd}$ & $18.4 \pm 3.29 \mathrm{a}$ \\
\hline Spermine 50 & $8.2 \pm 2.86 \mathrm{c}$ & $8.0 \pm 1.79 \mathrm{~b}$ & $15.8 \pm 4.27 \mathrm{ab}$ & $16.0 \pm 2.16 \mathrm{abc}$ \\
\hline Spermine 100 & $7.5 \pm 2.43 \mathrm{c}$ & $10.8 \pm 1.50 \mathrm{ab}$ & $12.0 \pm 3.46 \mathrm{bcd}$ & $16.8 \pm 3.40 \mathrm{ab}$ \\
\hline Effect & $P=0.00$ & $P=0.05$ & $P=0.00$ & $P=0.01$ \\
\hline \multicolumn{5}{|c|}{ Mean bulb mass ( $\mathrm{mg}$ ) } \\
\hline Control & $310.4 \pm 42.90 \mathrm{~b}$ & $372.6 \pm 45.0 \mathrm{bcd}$ & $113.3 \pm 43.57 \mathrm{ab}$ & $257.3 \pm 60.01 \mathrm{a}$ \\
\hline Ornithyne 500 & $279.3 \pm 82.87 \mathrm{~b}$ & $474.8 \pm 52.2 \mathrm{ab}$ & $72.0 \pm 28.62 \mathrm{a}-\mathrm{c}$ & $256.5 \pm 72.08 \mathrm{a}$ \\
\hline Ornithyne 1000 & $243.2 \pm 67.00 \mathrm{~b}$ & $584.9 \pm 46.3 \mathrm{a}$ & $65.1 \pm 30.45 \mathrm{bc}$ & $257.6 \pm 35.36 \mathrm{a}$ \\
\hline Arginine 500 & $234.2 \pm 71.13 b$ & $456.2 \pm 95.9 \mathrm{ab}$ & $120.2 \pm 39.72 \mathrm{a}$ & $300.6 \pm 43.88 \mathrm{a}$ \\
\hline Arginine 1000 & $326.1 \pm 151.04 \mathrm{~b}$ & $422.0 \pm 70.5 \mathrm{~b}$ & $90.3 \pm 37.93 \mathrm{a}-\mathrm{c}$ & $248.6 \pm 45.33 a$ \\
\hline Putrescine 50 & $277.0 \pm 50.15 \mathrm{~b}$ & $408.4 \pm 96.7 \mathrm{bc}$ & $86.9 \pm 44.92 \mathrm{a}-\mathrm{c}$ & $282.2 \pm 61.56 \mathrm{a}$ \\
\hline Putrescine 100 & $252.3 \pm 67.97 \mathrm{~b}$ & $445.9 \pm 113.2 \mathrm{~b}$ & $71.2 \pm 29.00 \mathrm{a}-\mathrm{c}$ & $231.57 \pm 85.52 a$ \\
\hline Spermine 50 & $246.5 \pm 48.64 \mathrm{~b}$ & $283.8 \pm 77.5 \mathrm{~cd}$ & $66.4 \pm 18.59 \mathrm{bc}$ & $230.8 \pm 64.59 a$ \\
\hline Spermine 100 & $423.1 \pm 36.75 \mathrm{a}$ & $261.7 \pm 36.5 \mathrm{~cd}$ & $48.4 \pm 22.23 \mathrm{c}$ & $260.5 \pm 156.29 a$ \\
\hline Effect & $P=0.00$ & $P=0.00$ & $P=0.05$ & $P=0.95$ \\
\hline
\end{tabular}

* Mean separation within columns by Duncan's multiple range test. The mean $\pm \mathrm{SD}(\mathrm{n}=5)$ followed by the same letter do not differ at $P=0.05$

** $P$ value in italic means that effect is significant phases; the lowest values were generally noted at the final bulbing phase S5.

\section{Polyamine tissue contents at S4 and S5 depending on exogenous PA/AA treatments and genotype}

Exogenously applied AAs and PAs (added to the bulbing medium before cooling) strongly influenced tissue contents of polyamines measured in bulbing shoots of FB and NB at S4 (just after the end of cooling) and six weeks later, at S5.
At S4, putrescine accumulation (728.3-817.5 $\mathrm{nmol} \mathrm{g}^{-1}$ FM) in NB shoots was markedly enhanced by exogenously applied Orn and Spm. Unexpectedly, the exogenously applied putrescine strongly reduced tissue content of this polyamine (140.0 $\left.\mathrm{nmol} \mathrm{g}{ }^{-1} \mathrm{FM}\right)$ compared to the control (302.0 nmol g ${ }^{-1}$ FM) (Fig. 4a). At the same time, Put tissue contents were much higher in NB compared to FB. Six weeks later, at S5, Put contents drastically decreased in NB; in control, Put level was even twofold lower than in FB (92.9 $\mathrm{nmol} \mathrm{g}^{-1} \mathrm{FM}$ ) (Fig. 4b). However, in PA/ 
Table 3 Bulb formation in vitro of the tulip cultivar NB following the treatments with polyamines and amino acids given after the end of low temperature treatment (S4) depending on MeJA treatment; data recorded 13 weeks after cooling; probability value $(P)$ of $F$ test from two-factor analysis of variance of the bulb formation parameters

\begin{tabular}{lll}
\hline Treatment $(\mu \mathrm{M})$ & \multicolumn{2}{l}{ MeJA } \\
\cline { 2 - 3 } & - & + \\
\hline Total bulb number & & $13.8 \mathrm{~d}$ \\
Control & $19.7 \mathrm{abc} *$ & $21.8 \mathrm{a}$ \\
Ornithine 500 & $17.6 \mathrm{abcd}$ & $16.0 \mathrm{bcd}$ \\
Arginine 500 & $19.2 \mathrm{abc}$ & $14.0 \mathrm{~d}$ \\
Putrescine 50 & $15.3 \mathrm{~cd}$ & $18.3 \mathrm{abcd}$ \\
Spermidine 50 & $19.2 \mathrm{abc}$ & $17.7 \mathrm{abcd}$ \\
Spermine 50 & $20.7 \mathrm{ab}$ &
\end{tabular}

\begin{tabular}{lll}
\hline Effect & $P$ & \\
\hline AA/polyamines & $0.01^{* * *}$ & \\
MeJA & 0.04 & \\
AA/polyamines × MeJA & 0.07 & \\
Total number of regular bulbs & & $12.5 \mathrm{c}$ \\
Control & $16.6 \mathrm{ab}$ & $18.0 \mathrm{a}$ \\
Ornithine 500 & $13.4 \mathrm{abc}$ & $14.2 \mathrm{abc}$ \\
Arginine 500 & $14.6 \mathrm{abc}$ & $10.2 \mathrm{c}$ \\
Putrescine 50 & $12.6 \mathrm{c}$ & $13.3 \mathrm{abc}$ \\
Spermidine 50 & $16.8 \mathrm{ab}$ & $13.7 \mathrm{abc}$ \\
Spermine 50 & $16.5 \mathrm{ab}$ &
\end{tabular}

\begin{tabular}{lll}
\hline Effect & $P$ & \\
\hline AA/polyamines & 0.09 & \\
MeJA & 0.14 & \\
AA/polyamines $\times$ MeJA & 0.13 & \\
Mean bulb mass (mg) & & $288.8 \mathrm{ab}$ \\
Control & $198.9 \mathrm{bc}$ & $306.4 \mathrm{a}$ \\
Ornithine 500 & $298.9 \mathrm{a}$ & $277.8 \mathrm{ab}$ \\
Arginine 500 & $248.7 \mathrm{ab}$ & $260.3 \mathrm{ab}$ \\
Putrescine 50 & $332.4 \mathrm{a}$ & $263.5 \mathrm{ab}$ \\
Spermidine 50 & $157.2 \mathrm{c}$ & $328.2 \mathrm{a}$ \\
Spermine 50 & $298.4 \mathrm{a}$ &
\end{tabular}

\begin{tabular}{ll}
\hline Effect & $P$ \\
\hline AA/polyamines & 0.00 \\
MeJA & 0.06 \\
AA/polyamines $\times$ & 0.05 \\
$\quad$ MeJA &
\end{tabular}

* Mean separation within each bulb growth parameter by Duncan's multiple range test. The mean $\pm \mathrm{SD}(\mathrm{n}=5)$ followed by the same letter do not differ at $P=0.05$

** $P$ value in italic means that effect is significant

AA treatments, Put tissue contents in NB remained slightly higher than in FB, with the highest value found for Orn treatment (113.1 $\left.\mathrm{nmol} \mathrm{g}^{-1} \mathrm{FM}\right)$.

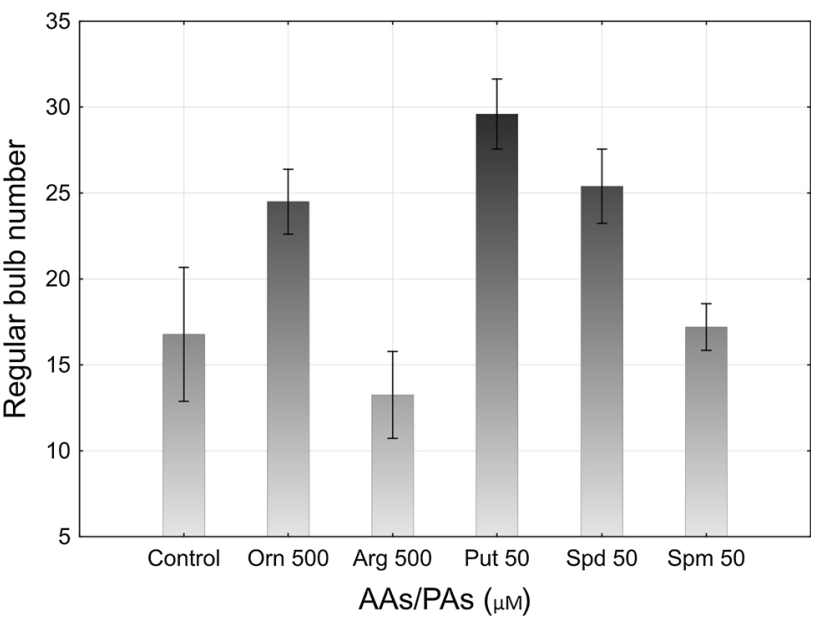

Fig. 2 Regular bulb number of tulip cultivar P14 under treatments with amino acids (Orn and Arg) and polyamines (Put, Spd and Spm) added to the medium just after the end of cooling (S4); Mean \pm SD $(\mathrm{n}=5), P=0.00$

At S4, spermidine tissue contents were not influenced by AA/PA treatments and were similar in both cultivars, irrespective of exogenously applied AAs/PAs, ranging from ca. 269 to $342 \mathrm{nmol} \mathrm{g}^{-1} \mathrm{FM}$ (Fig. 4c). The significant effects of AAs and PAs were visible six weeks later (S5) when Spd levels decreased, especially in FB. In this cultivar, the lowest Spd level (71.8 $\left.\mathrm{nmol} \mathrm{g}^{-1} \mathrm{FM}\right)$ was observed with the Put treatment and the highest Spd level (131.8 $\mathrm{nmol} \mathrm{g}^{-1} \mathrm{FM}$ ) was recorded in control (Fig. 4d). In NB treated with exogenous Orn or Spm, the Spd contents decreased slightly at S5 compared to S4 but were still relatively high: 262.4 and $201.1 \mathrm{nmol} \mathrm{g}^{-1} \mathrm{FM}$, respectively.

Spermine tissue contents at S4 were generally higher in FB than in NB. Compared to control, a significant increase in Spm accumulation was noted at S4 and S5 in both cultivars when exogenous Spm was added to the medium (Fig. 4e, f). In NB, the marked increase of Spm tissue content was also recorded for Orn and Arg treatments at S4. Interestingly, Orn application resulted in decrease of $\mathrm{Spm}$ at S5. In FB, the significant enhancement of Spm accumulation was visible 6 weeks later (at S5) for all of the AA/PA treatments.

\section{Discussion}

Our research on micropropagated tulips showed that the effects of PAs or their precursors were highly dependent on genotype, application term, compound concentration and MeJA treatment. Positive effects of PAs or AAs on bulb formation in vitro were generally found in cultivar NB, with the lowest bulbing ability. All of the studied AAs (Arg and Orn) and PAs (Put and Spm) markedly enhanced bulb 
Table 4 Bulb formation in vitro of the tulip cultivars NB and P14 following the treatments with polyamines and amino acids given 6 weeks after the end of low temperature treatment (S5) depending on
MeJA treatment; data recorded 13 weeks after cooling; probability value $(P)$ of $F$ test from two-factor analysis of variance of the bulb formation parameters

\begin{tabular}{|c|c|c|c|c|}
\hline \multirow[t]{4}{*}{ Treatment $(\mu \mathrm{M})$} & \multicolumn{4}{|l|}{ Genotype } \\
\hline & \multicolumn{2}{|l|}{ NB } & \multicolumn{2}{|l|}{ Pol-14 } \\
\hline & \multicolumn{4}{|l|}{ MeJA } \\
\hline & - & + & - & + \\
\hline \multicolumn{5}{|l|}{ Total bulb number } \\
\hline Control & $21.8 \pm 3.60 \mathrm{abc}^{*}$ & $16.6 \pm 3.36 \mathrm{c}$ & $63.0 \pm 13.25 \mathrm{bcd}$ & $71.2 \pm 16.51 \mathrm{abc}$ \\
\hline Ornithine 500 & $19.3 \pm 2.29 \mathrm{bc}$ & $17.7 \pm 1.03 \mathrm{c}$ & $77.3 \pm 5.50 \mathrm{ab}$ & $66.8 \pm 115.7 \mathrm{abcd}$ \\
\hline Arginine 500 & $21.8 \pm 4.17 \mathrm{abc}$ & $18.7 \pm 2.16 \mathrm{bc}$ & $82.7 \pm 2.87 \mathrm{a}$ & $64.0 \pm 8.29 \mathrm{bcd}$ \\
\hline Putrescine 50 & $20.3 \pm 3.30 \mathrm{abc}$ & $18.3 \pm 4.03 \mathrm{bc}$ & $79.0 \pm 12.03 \mathrm{ab}$ & $50.7 \pm 14.35 \mathrm{~d}$ \\
\hline Spermidine 50 & $23.9 \pm 5.61 \mathrm{ab}$ & $20.0 \pm 6.65 \mathrm{abc}$ & $79.8 \pm 13.48 \mathrm{ab}$ & $62.4 \pm 8.79$ bcd \\
\hline Spermine 50 & $25.6 \pm 7.18 \mathrm{a}$ & $16.3 \pm 7.31 \mathrm{c}$ & $56.2 \pm 5.63 \mathrm{~cd}$ & $59.4 \pm 9.61 \mathrm{bcd}$ \\
\hline Effect & $P$ & & & \\
\hline AA/polyamines & 0.42 & & 0.07 & \\
\hline MeJA & $0.00 * *$ & & 0.00 & \\
\hline AA/polyamines $\times$ MeJA & 0.35 & & 0.01 & \\
\hline \multicolumn{5}{|c|}{ Number of regular bulbs (>100 mg) } \\
\hline Control & $11.3 \pm 2.58 \mathrm{ab}$ & $7.6 \pm 2.37 \mathrm{c}$ & $6.2 \pm 0.84 \mathrm{bcd}$ & $6.8 \pm 1.48 \mathrm{bcd}$ \\
\hline Ornithine 500 & $10.6 \pm 1.90 \mathrm{abc}$ & $9.0 \pm 1.79 \mathrm{bc}$ & $7.0 \pm 2.16 \mathrm{abcd}$ & $7.3 \pm 1.63 \mathrm{abcd}$ \\
\hline Arginine 500 & $11.0 \pm 1.10 \mathrm{abc}$ & $10.5 \pm 1.64 \mathrm{abc}$ & $5.0 \pm 0.82 \mathrm{~d}$ & $9.5 \pm 3.00 \mathrm{a}$ \\
\hline Putrescine 50 & $12.0 \pm 4.16 \mathrm{ab}$ & $10.4 \pm 3.21 \mathrm{abc}$ & $7.8 \pm 2.06 \mathrm{abcd}$ & $5.5 \pm 1.97 \mathrm{~cd}$ \\
\hline Spermidine 50 & $13.3 \pm 4.11 \mathrm{a}$ & $8.4 \pm 2.56 \mathrm{bc}$ & $9.0 \pm 1.00 \mathrm{a}$ & $7.0 \pm 1.87 \mathrm{bcd}$ \\
\hline \multirow[t]{2}{*}{ Spermine 50} & $11.3 \pm 2.56 \mathrm{ab}$ & $8.0 \pm 2.97 \mathrm{bc}$ & $8.0 \pm 2.12 \mathrm{abc}$ & $5.8 \pm 2.28 \mathrm{~cd}$ \\
\hline & $P$ & & & \\
\hline AA/polyamines & 0.45 & & 0.54 & \\
\hline MeJA & 0.00 & & 0.74 & \\
\hline AA/polyamines $\times$ MeJA & 0.32 & & 0.01 & \\
\hline \multicolumn{5}{|c|}{ Total number of regular bulbs } \\
\hline Control & $20.5 \pm 2.59 \mathrm{abc}$ & $14.1 \pm 4.18 \mathrm{~d}$ & $47.6 \pm 11.48 \mathrm{~cd}$ & $52.0 \pm 11.42$ abcd \\
\hline Ornithine 500 & $17.0 \pm 2.00 \mathrm{abcd}$ & $15.2 \pm 2.40 \mathrm{~cd}$ & $55.8 \pm 5.00 \mathrm{abcd}$ & $54.0 \pm 14.20$ abcd \\
\hline Arginine 500 & $19.0 \pm 3.40$ abcd & $18.0 \pm 3.03 \mathrm{abcd}$ & $63.0 \pm 2.45 \mathrm{ab}$ & $51.3 \pm 13.18$ abcd \\
\hline Putrescine 50 & $18.1 \pm 3.24$ abcd & $15.7 \pm 2.98 \mathrm{bcd}$ & $60.3 \pm 8.62$ abcd & $43.0 \pm 12.82 \mathrm{~d}$ \\
\hline Spermidine 50 & $20.9 \pm 5.81 \mathrm{ab}$ & $15.6 \pm 5.78 \mathrm{bcd}$ & $67.2 \pm 5.17 \mathrm{a}$ & $48.8 \pm 7.90 \mathrm{bcd}$ \\
\hline \multirow[t]{2}{*}{ Spermine 50} & $22.0 \pm 6.32 \mathrm{a}$ & $13.8 \pm 6.08 \mathrm{~d}$ & $43.4 \pm 4.77 \mathrm{~cd}$ & $53.6 \pm 17.78$ abcd \\
\hline & \multicolumn{2}{|l|}{$P$} & & \\
\hline AA/polyamines & 0.72 & & 0.08 & \\
\hline MeJA & 0.00 & & 0.06 & \\
\hline AA/polyamines $\times$ MeJA & 0.24 & & 0.12 & \\
\hline \multicolumn{5}{|l|}{ Mean bulb mass (mg) } \\
\hline Control & $194.9 \pm 29.23 \mathrm{ab}$ & $190.2 \pm 26.66 \mathrm{ab}$ & $66.3 \pm 15.97 \mathrm{abcd}$ & $52.7 \pm 10.14 \mathrm{~cd}$ \\
\hline Ornithine 500 & $212.7 \pm 24.71 \mathrm{ab}$ & $182.2 \pm 27.52 b$ & $58.7 \pm 7.77 \mathrm{bcd}$ & $75.1 \pm 20.99 a b$ \\
\hline Arginine 500 & $212.7 \pm 39.80 \mathrm{ab}$ & $185.9 \pm 39.83 \mathrm{~b}$ & $49.5 \pm 8.65 \mathrm{~d}$ & $80.4 \pm 16.86 \mathrm{a}$ \\
\hline Putrescine 50 & $197.1 \pm 38.86 \mathrm{ab}$ & $218.6 \pm 48.19 \mathrm{ab}$ & $61.9 \pm 1.88$ abcd & $55.7 \pm 10.07 \mathrm{bcd}$ \\
\hline Spermidine 50 & $245.0 \pm 44.20 \mathrm{a}$ & $186.5 \pm 47.52 b$ & $62.4 \pm 9.65$ abcd & $71.1 \pm 12.40 \mathrm{abc}$ \\
\hline Spermine 50 & $220.1 \pm 20.22 \mathrm{ab}$ & $218.3 \pm 65.72 \mathrm{ab}$ & $70.6 \pm 10.49 \mathrm{abc}$ & $62.5 \pm 8.83 \mathrm{abcd}$ \\
\hline
\end{tabular}


Table 4 continued

\begin{tabular}{lll}
\hline & $P$ & 0.51 \\
\hline AA/polyamines & 0.60 & 0.17 \\
MeJA & 0.09 & 0.25 \\
AA/polyamines $\times$ MeJA & 0.01 \\
* Mean separation within each bulb growth parameter by Duncan's multiple range test. The mean \pm SD $(\mathrm{n}=5)$ followed by the same letter do \\
not differ at $P=0.05$
\end{tabular}

numbers in this cultivar when used at lower concentrations at the beginning of the bulbing process (before cooling, at S3), together with standard MeJA treatment, and only Spm increased the bulb mass. In other cultivars, FB, P14 and P20, all with high bulbing ability, PAs and AAs substantially did not influence or even markedly reduce bulbing efficiency. As in tulip cultivar NB, bulb formation improvement by the application of different PAs or AAs was obtained for Lilium longiflorum as well (Tanimoto and Matsubara 1995). In this lily species, the most effective was Spm at $100 \mu \mathrm{M}$. Also, Varshney et al. (2000) showed that the incorporation of Spm $(150 \mathrm{mM})$ or Put $(50 \mu \mathrm{M})$ to culture medium stimulated bulblet multiplication of lily Asiatic hybrids. In their study, however, mean bulb mass did not show any significant increase. In our study, the increment of the bulb mass was expected most of all in cultivar P14. That was achieved at Arg treatment given at S5 combined with MeJA application.

Corresponding data for the positive role of Arg in tulip bulb formation were reported by Le Nard and Fiala (1990). They found that high Arg content in mother bulbs (in vivo) before low temperature treatment was correlated with the subsequent more efficient formation of daughter bulbs. In turn, Kollöffel et al. (1992), monitoring levels of free PAs in the various parts the tulip bulbs in vivo during the 12 week-storage at different temperatures $\left(5\right.$ or $\left.17^{\circ} \mathrm{C}\right)$, found that irrespective of the temperature all free PA contents increased during storage and Spd dominated in all bulb parts.

More evidence for the role of PAs in storage organ formation in vitro have been reported for tuberous geophytes. Thus, Put, Spd and Spm at 100 or $500 \mu \mathrm{M}$ increased the number of gladiolus cormlets, with the maxima observed for Spd treatment (Kumar et al. 2011). That was similar to our results concerning tulip cultivar $\mathrm{NB}$, in which all these compounds enhanced number of bulbs. An advantageous effect of Spd $(1 \mu \mathrm{M})$ was also demonstrated for potato tuber formation (Mader 1995). In yam, both PAs (Put, Spd and Spm) and AAs (Arg and Orn) added to a medium at various concentrations $(1-1000 \mu \mathrm{M})$ markedly accelerated tuber development, and significantly enhanced tuber sizes (Ondo Ovono et al. 2010a, b).
Analysis of the endogenous PA contents and patterns have provided additional evidence of polyamine role in bulbing process. We found that Put was the major polyamine in three tulip genotypes at the stages of shoot multiplication (S1-S2), in the presence of TDZ and/or iP. Then, Put levels progressively declined in all of the cultivars and were lowest at the final bulbing stage (S5). Spd manifested similar dynamics in all of the cultivars, showing two peaks: at shoot multiplication (S2) and at the end of cooling (S4). Spm contents were generally higher at multiplication stages (S1-S2), mainly in the cultivars producing bulbs easily (FB and $\mathrm{P} 14$ ). Then, its contents declined to the lowest levels at the final bulbing stage (S5), except for cultivar NB, in which Spm increased at this time. This phase in the cultivars easily forming bulbs (FB, P20 and P14) was associated with the commencement of bulb enlargement and the simultaneous development of dormancy manifesting with leaf yellowing, as previously reported for another easy bulbing tulip cultivar 'Prominence' (Podwyszyńska et al. 2014). In the cultivar NB, such symptoms were not visible at S5 (6 weeks after the end of cooling). Bulbs of this cultivar started to enlarge 4 weeks later than in other cultivars and leaf yellowing was visible even later, about 12-13 weeks after cooling.

As in our study, high endogenous Put level at the multiplication stage was detected in shoots of taro (Colocasia esculenta), while exogenously applied Spd or Spm induced tuberisation (Francisco et al. 2008). Considering these results and our data, we concluded that the transient increase of Spd levels after the low temperature treatment (S4) associated with dormancy release could be involved in the initiation of the bulbing process. This phase of bulb or any other storage organs development (e.g. tubers or corms) characterized with cell differentiation into storage tissue (De Hertogh and Le Nard 1993; Rees 1992; Podwyszyńska 2012). We further observed that despite the fact that Spd content decreased at S5 together with other PAs, Spd was generally the major polyamine at the final bulbing stages (S4 and S5). This Spd prevalence was evidenced by the generally low Put/Spd ratios in all of the cultivars at the final bulbing phase. In three cultivars these ratios were 

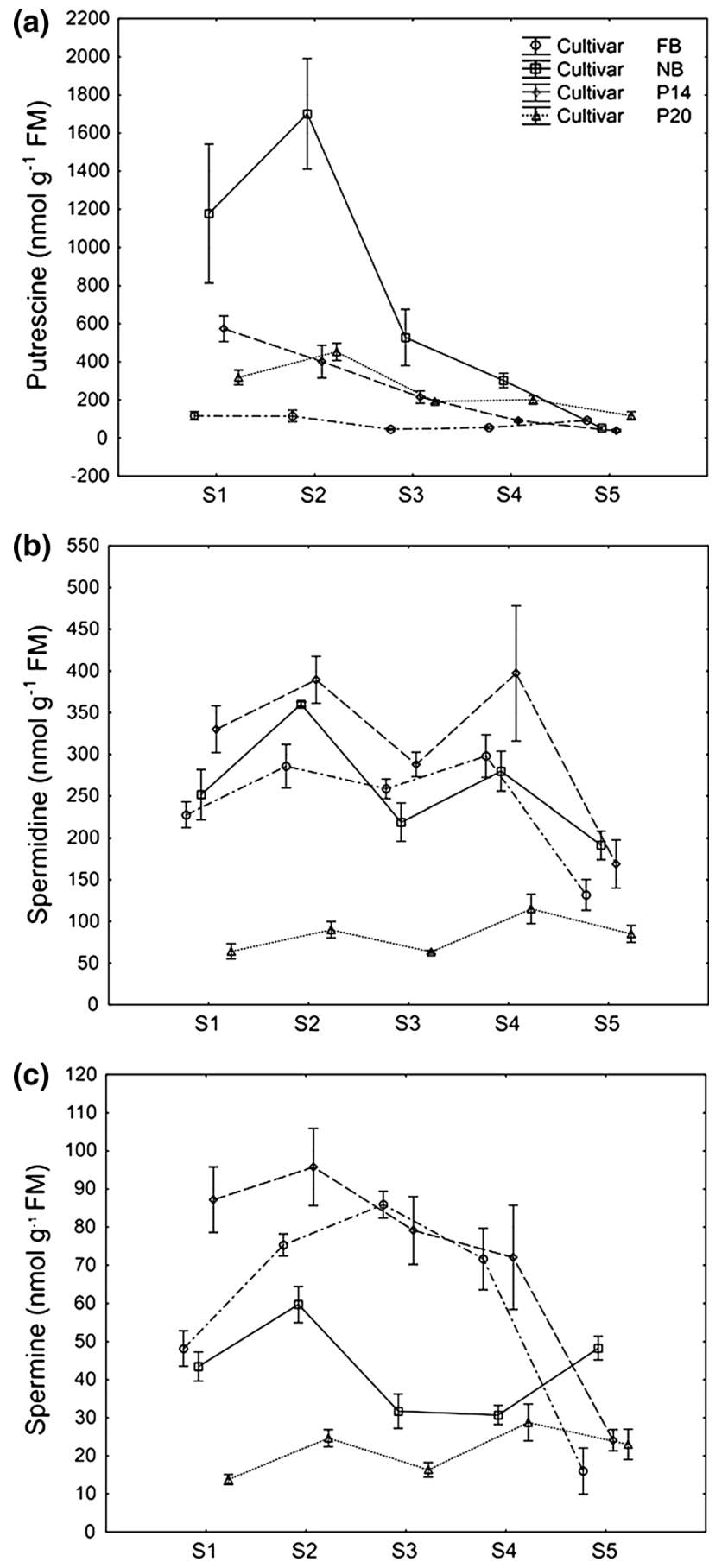

Fig. 3 Contents of endogenous polyamines in the in vitro shoots/ bulbing shoots of the tulip cultivars 'Fringed Black' (FB), 'New Beet' (NB), P14 and P20 during successive micropropagation stages: S1, after 6 weeks of the standard multiplication subculture; S2, at the fifth week of the last multiplication subculture; S3, 5 weeks later-just before cold treatment; S4, at the end of the 13-week-cold treatment; S5, 6 weeks after the end of cold treatment (at the shoot base swelling/bulb formation phase); mean $\pm \mathrm{SE}(\mathrm{n}=4), F$ and $P$ for ANOVA Phase $\times$ Cultivar are given for each endogenous polyamine: a putrescine: $F=6.8, P=0.00$, b spermidine: $F=2.6, P=0.01$, c spermine: $F=9.22, P=0.00$ below 1 and in one cultivar it was ca. 1.4. Earlier, analogous hypothesis that tuberising conditions in potato characterized with low Put/Spd ratios, below 1, was reported by Mader (1995). All of these observations correspond to the reported findings that Put is the most abundant at cell division, but Spd and Spm are essential for inducing cell differentiation, as reviewed by Bais and Ravishankar (2002) and Anwar et al. (2015).

Our results have provided other interesting evidence on the role of Spd in the bulbing process. In cultivar FB, with extremely high bulbing ability, Spd prevalence was observed at all of the micropropagation stages, even at shoot multiplication. Besides, the shoots of this cultivar, unlike other genotypes, have a tendency to produce some bulbs, even under non-inducing conditions, i.e. during shoot multiplication in the presence of cytokinins, without low temperature treatment.

In turn, Kumar and Palni (2013) noted that the levels of all PAs showed an increase during the middle phase of gladiolus cormlet development in vitro and Spd was found to be the major polyamine. Then PA levels declined during cormlet maturation. We also demonstrated that the contents of all of the PAs decreased in developing bulbs. We suppose that it could be associated with ABA increment and dormancy development of tulip bulbing shoots (Podwyszynska et al. 2004). Furthermore, we postulated that low bulbing ability of the cultivar NB may be related to the up-regulation of Spm biosynthesis at S5, since all PA levels, including Spm, declined in all of the cultivars producing bulbs easily. We suppose that such Spm increase at S5 could interfere in dormancy development in the NB cultivar.

Morphogenic responses of tulip shoots in vitro to polyamines and their precursors can be better understood in light of numerous evidences showing that polyamines and PGRs such as ethylene, auxins, cytokinins and ABA mutually influenced the metabolism of each other, as well as the actions and translocation (Bais and Ravishankar 2002; Anwar et al. 2015). The authors cited numerous reports on interactions between polyamines and PGRs in several morphogenic and physiological processes such as, e.g. cell division and senescence. Since PAs and ethylene derive from and compete for a common precursor S-adenosylmethionine (SAM), and ethylene is known to stimulate senescence, the polyamines are considered to counteract this process, e.g. leaf senescence (Bais and Ravishankar 2002; Anwar et al. 2015). The results of our study indicate that delayed leaf senescence and bulb formation in cultivar NB can be associated with higher levels of endogenous Spm at the final bulbing stage compared to other cultivars. That could reduce the biosynthesis of ethylene, whereas it was found in our earlier study that 
Table 5 Rations of Put/Spd in shoots and bulbing shoots of micropropagated tulips of each cultivar, in each phase

\begin{tabular}{|c|c|c|c|c|c|}
\hline \multirow[t]{3}{*}{ Cultivar } & \multicolumn{5}{|l|}{ Put/Spd ratio } \\
\hline & \multicolumn{5}{|l|}{ Micropropagation phases } \\
\hline & $\begin{array}{l}\text { S1 6th week of standard } \\
\text { multiplication cubculture }\end{array}$ & $\begin{array}{l}\text { S2 5th week of the last } \\
\text { multiplication subculture }\end{array}$ & $\begin{array}{l}\text { S3 10th week of the last } \\
\text { multiplication subculture (befor } \\
\text { cooling) }\end{array}$ & $\begin{array}{l}\text { S4 13th week } \\
\text { of cooling }\end{array}$ & $\begin{array}{l}\text { S5 6th week } \\
\text { after cooling }\end{array}$ \\
\hline NB & 4.67 & 4.72 & 2.42 & 1.08 & 0.27 \\
\hline FB & 0.51 & 0.40 & 0.18 & 0.18 & 0.70 \\
\hline $\mathrm{P} 14$ & 1.74 & 1.03 & 0.74 & 0.23 & 0.23 \\
\hline P20 & 4.96 & 5.0 & 3.0 & 1.74 & 1.37 \\
\hline
\end{tabular}

ethylene promoted tulip bulb growth in vitro (Podwyszyńska 2006a).

Previous investigations revealed that the low bulbing ability and related delayed leaf yellowing of another tulip cultivar 'Blue Parrot' was associated with large CK accumulation during last phase of the bulb formation (Podwyszyńska et al. 2014). Rakova and Romanov (2005) based on their studies with seedling of transgenic Arabidopsis indicated that endogenous PAs can significantly modulate an amplitude of a CK primary response gene expression in vivo. These authors speculated that cytokinin-induced accumulation of PAs (Sergiev et al. 1995) can be a response, alleviating the consequences of plant treatment with excessive CK doses. Such a situation could occur in the NB shoots at multiplication stages (S1-S2) when this cultivar exhibits extremely high Put levels and a subsequent drastic drop at S3, as the response to high cytokinin level at S1.

Ondo Ovono et al. (2010a, b) reported that treatment with Put $\left(10^{-5} \mathrm{M}\right)$ resulted in a dramatic increase in the contents of both endogenous auxin (ten times) and Put in yam tubers, which was associated with better tuber development. Such PA-mediated auxin increment could promote tulip bulb development in the present study, since we found positive effects of exogenous auxins on tulip bulb formation in our previous investigation (Podwyszyńska 2006a, b). Furthermore, Ondo Ovono et al. (2010a, b) demonstrated that exogenous Put at the concentrations of 0.1-10 $\mu \mathrm{M}$ (improving tuber formation) did not influence endogenous Put content at the stage when the tuber was already formed and had already grown. However, the addition of polyamines at higher concentrations $(1000 \mu \mathrm{M})$ in plant medium enhanced their accumulation in a plant tissue, while it delayed tuber formation. This partly corresponds with our observation referring to the cultivar NB. Thus, shoots of this cultivar characterized with extremely high Put levels at S1 and S2 that could affect subsequent bulb formation retarding this process. This supposition ca be further confirmed by our observations that the exogenous Put decreased its tissue content contrary to the mentioned above results obtained for yam tubers (Ondo Ovono 2010a). Our results indicate a negative feedback regulation of this PA that is in agreement with the known mechanism of maintaining PA homeostasis through one of the mechanisms, e.g. polyamine (Spd and Spm) catabolism catalysed by polyamine oxidases (Ahou et al. 2014) and Put oxidation by copper containing amine oxidase (Tavladoraki et al. 2012). PAs themselves can induce alterations in the expression levels of genes involved in PA metabolism through various regulatory mechanisms, including inhibitory molecules, as reviewed by Ahou et al. (2014) and Anwar et al. (2015).

We observed strong interaction between PAs and MeJA. The cultivar NB of low bulbing ability responded to MeJA application different to other genotypes. Although MeJA was found to significantly improve bulb formation of several micropropagated tulip cultivars (Podwyszyńska 2006a; Podwyszyńska and Sochacki 2010), the NB shoots treated with MeJA alone produced a similar or even smaller number of bulbs compared to untreated shoots. Instead, AA/PA in combination with MeJA treatment enhanced the number of bulbs obtained. Contrary to our results, Ondo Ovono et al. (2010b) reported that both PAs and MeJA had positive effects on in vitro tuberisation of Dioscorea when applied alone and negative when in combination. On the other hand, Biondi et al. (2001) showed that MeJA treatments decreased the endogenous levels of free PAs while increasing the accumulation of their conjugates. These authors also found that depletion of the free PA pool occurred in spite of the activation of all biosynthetic enzymes, such as Arg, Orn and S-adenosylmethionine decarboxylases. They supposed that free PAs were utilised to form conjugates. Moreover, Biondi et al. (2001) revealed that diamine oxidase (DAO) activity was also stimulated by MeJA and DAO was suggested to generate the hydrogen peroxide needed in cell expansion and/or lignification (Angelini et al. 1993, cited after Biondi et al. 2001). In general, cell enlargement is characteristic of the later stages of tuberisation process such as initiation and growth of 

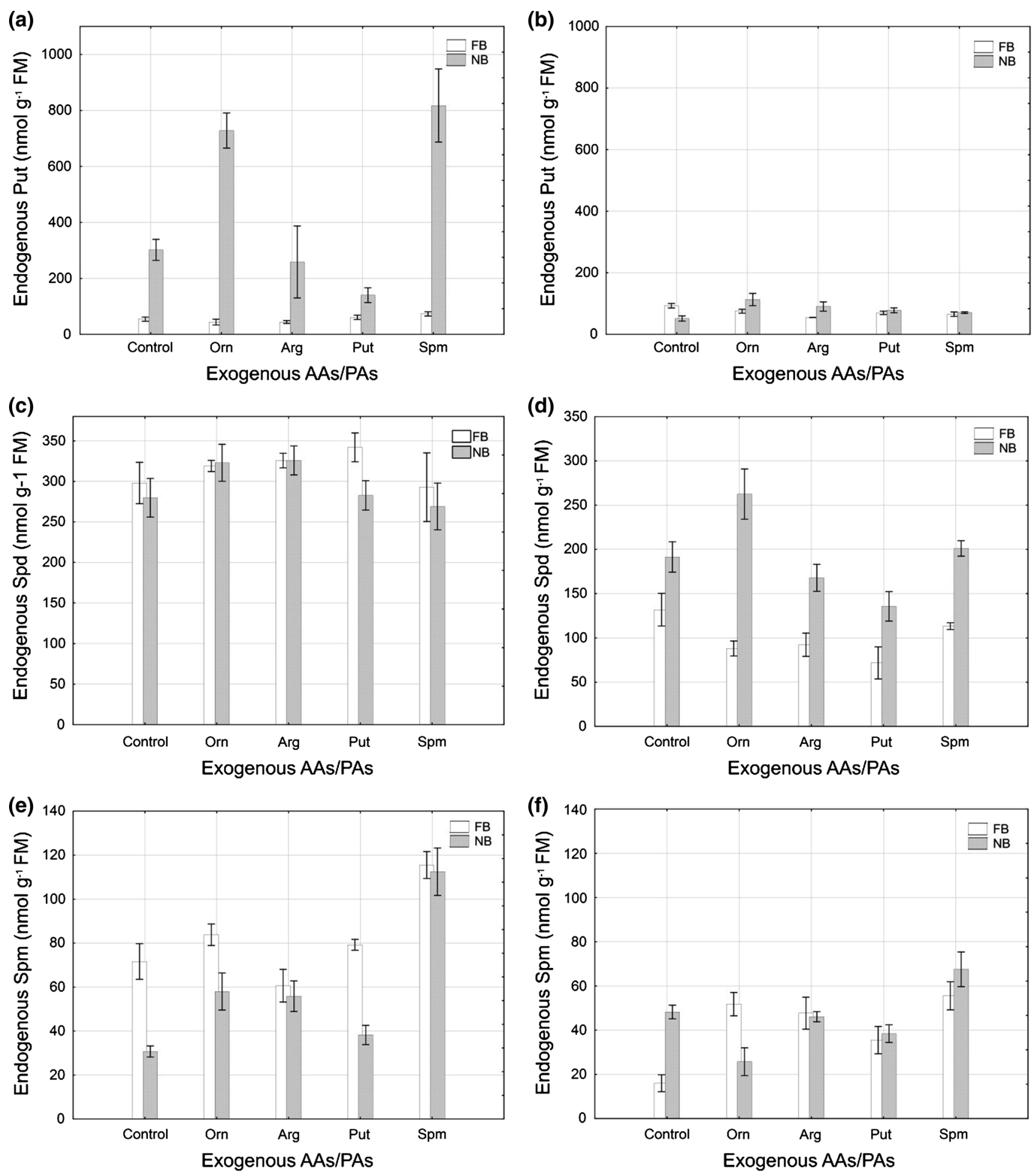

Fig. 4 Tissue contents of polyamines in the in vitro bulbing shoots of the tulip cultivars 'Fringed Black' (FB) and 'New Beet' (NB) at bulbing stages $\mathrm{S} 4$ (a, c, e) (at the end of the 13-week-cold treatment) and S5 (b, d, f) (6 weeks after the end of cold treatment) followed treatments with exogenous amino acids (Orn and Arg) and polyamines (Put, Spd and Spm) added to the medium before cold treatment

$(\mathrm{S} 3)$; mean $\pm \mathrm{SE}(\mathrm{n}=4), F$ and $P$ for ANOVA cultivar $\times$ exogenous AA/PA for each tissue content polyamine at $\mathrm{S} 4$ or $\mathrm{S} 5$ are as follows: a putrescine S4: $F=11.2, P=0.00, \mathbf{b}$ putrescine $\mathrm{S} 5$ : $F=5.4, P=0.00 ;$ c spermidine $\mathrm{S} 4: F=0.6, P=0.68 ;$ d spermidine S5: $F=4.3, P=0.01$; e spermine S4: $F=3.8, P=0.01$; f spermine $\mathrm{S} 5: F=6.9, P=0.00$ 
storage organs (De Hertogh and Le Nard 1993; Rees 1992; Podwyszyńska 2012). Besides, storage organ initiation is associated with reorientation of the direction of both cell division and radial expansion in the region of subsequent swelling (Koda 1997; Vreughdenhil et al. 1999), that has been demonstrated to be induced by jasmonates in tuber formation from stolon apex in potato (Koda 1997; Cenzano et al. 2003) and bulbs from leaf sheath in onion or leaf bases in narcissus (Nojiri et al. 1992; Koda 1997; Zaffryar et al. 2007).

Modulation of hormonal status by polyamines during tulip bulb formation is a complex and long-lasting process. PAs positively influenced bulb formation of the low bulbing ability cultivar NB when applied before low temperature treatment. Since PAs were reported to increase IAA and ABA contents (Ondo Ovono et al. 2010a, b; Steiner et al. 2007) and modulate CK contents (Biondi et al. 2003; Rakova and Romanov 2005), they could positively influence bulb formation of the tulip through mutual interactions with these hormones. This assumption is consistent with the general summary of information, referring to the changes in transcriptome linked to the plant hormone/ polyamine interactions presented by Anwar et al. (2015). The authors concluded that Put was positively related to the expression of genes regulating ABA biosynthesis but down-regulated genes of ethylene, jasmonates, and gibberellin biosynthesis, while the Spd action was found to be exactly opposite. Spm enhanced genes for ethylene and jasmonates biosynthesis but down-regulated those for gibberellins and ABA biosynthesis.

Considering all of the acquired data, we postulate that the high bulbing competence may be related to a transient increase in Spd content in response to low temperature treatment (S4), followed by its rapid decrease during bulb growth and maturation (S5, 6 weeks after the end of cooling) when developing bulbs begin to enter dormancy. The low levels of all free PAs at final bulbing stage as well as low Put/Spd ratio may also aid in the bulb formation of tulip in vitro.

Open Access This article is distributed under the terms of the Creative Commons Attribution 4.0 International License (http://creative commons.org/licenses/by/4.0/), which permits unrestricted use, distribution, and reproduction in any medium, provided you give appropriate credit to the original author(s) and the source, provide a link to the Creative Commons license, and indicate if changes were made.

\section{References}

Ahou A, Martignago D, Alabdallah O, Tavazza R, Stano P, Macone A, Tavladoraki P (2014) A plant spermine oxidase/dehydrogenase regulated by the proteasome and polyamines. J Exp Bot 65:1585-1603
Angelini R, Bragaloni M, Federico R, Infantino A, Porta-Puglia A (1993) Involvement of polyamines, diamine oxidase and peroxidase in resistance of chick-pea to Ascochyta rabiei. J Plant Physiol 142:704-709

Anwar R, Mattoo AK, Handa AK (2015) Polyamine interactions with plant hormones: crosstalk at several levels. In: Kusano T, Suzuki $\mathrm{H}$ (eds) Polyamines: universal molecular nexus for growth, survival, and specialized metabolism. Springer, Japan, pp 267-302

Ascough GD, Van Staden J, Erwin JE (2008) In vitro storage organ formation on ornamental geophytes. Hortic Rev 34:417-444

Bais HP, Ravishankar GA (2002) Role of polyamines in the ontogeny of plants and their biotechnological applications. Plant Cell Tissue Organ Cult 69:1-34

Biondi S, Scaramagli S, Capitani F, Altamura MM, Torrigiani P (2001) Methyl jasmonate upregulates biosynthetic gene expression, oxidation and conjugation of polyamines, and inhibits shoot formation in tobacco thin layers. J Exp Bot 52:231-242

Biondi S, Scoccianti V, Scaramagli S, Ziosi V, Torrigiani P (2003) Auxin and cytokinin modify methyl jasmonate effect on polyamine metabolism and ethylene biosynthesis in tobacco leaf discs. Plant Sci 165:95-101

Cenzano A, Vigliocco A, Kraus T, Abdala G (2003) Exogenously applied jasmonic acid induces changes in apical meristem morphology of potato stolons. Ann Bot 91:915-919

De Hertogh A, Le Nard M (1993) Physiology of flower bulbs. Elsevier Science, The Netherlands 811 pp

Flores HE, Galston AW (1982) Analysis of polyamines in higher plants by high performance liquid chromatography. Plant Physiol 69:701-706

Francisco AA, Tavares AR, Kanashiro S, Ramos PRR, Lima GPP (2008) Plant growth regulators in polyamines endogenous levels during the development of taro cultivated in vitro. Ciênc Rural 38:1251-1257

Gerrits MM, Kim KS, De Klerk GJ (1992) Hormonal control of dormancy in bulblets Lilium speciosum cultured in vitro. Acta Hort 325:521-527

Horbowicz M, Kosson R, Wiczkowski W, Koczkodaj D, Mitrus J (2011) Exogenously applied methyl jasmonate stimulates biosynthesis of 2-phenylethylamine and putrescine in seedlings of common buckwheat (Fagopyrum esculentum Moench). Acta Physiol Plant 33:897-903

Hussain SS, Ali M, Ahmad M, Siddique KH (2011) Polyamines: natural and engineered abiotic and biotic stress tolerance in plants. Biotechnol Adv 29:300-311

Ishimori T, Niimi Y, Han DS (2007) Benzyladenine and low temperature promote phase transition from juvenile to vegetative adult in bulblets of Lilium $\times$ formolongi 'White Aga' cultured in vitro. Plant Cell Tissue Organ Cult 88:313-318

Kakkar RK, Nagar PK, Ahuja PS, Rai VK (2000) Polyamines and plant morphogenesis. Biol Plant 43:1-11

Kaur-Sawhney R, Tiburcio AF, Altabella T, Galston AW (2003) Polyamines in plants: an overview. J Cell Mol Biol 2:1-12

Kim KS, Davelaar E, De Klerk GJ (1994) Abscisic acid controls dormancy development and bulb formation in lily plantlets regenerated in vitro. Physiol Plant 90:59-64

Kim EK, Hahn EJ, Murthy HN, Peak KY (2003) High frequency of shoot multiplication and bulblet formation of garlic in liquid cultures. Plant Cell Tissue Organ Cult 73:231-236

Koda Y (1997) Possible involvement of jasmonates in various morphogenic events. Physiol Plant 100:639-646

Kollöffel C, Geuns J, Lambrechts H (1992) Changes in free polyamine contents in tulip bulbs cv. Apeldoorn during dry storage. Acta Hort 325:247-252

Kosson R, Elkner K (2010) Effect of storage on biogenic amine content in sauerkraut. Veg Crops Res Bull 73:151-160 
Kosson R, Prange R (2005) The occurrence, physiological role and nutritive importance of polyamines in vegetables and fruits. Veg Crops Res Bull 65:5-24

Kumar A, Palni LMS (2013) Changes in endogenous polyamines during in vitro cormlet formation in Gladiolus hybridus Hort. Sci Hortic 162:260-264

Kumar A, Taylor MA, Mad Arif SA, Davies HV (1996) Potato plants expressing antisense and sense S-adenosylmethionine decarboxylase (SAMDC) transgenes show altered levels of polyamines and ethylene: antisense plants display abnormal phenotypes. Plant J 9:147-158

Kumar A, Palni LMS, Sood A (2011) Factors affecting in vitro formation of cormlets in Gladiolus hybridus Hort. and their field performance. Acta Physiol Plant 33:509-515

Langens-Gerrits MM, Miller WBM, Croes AF, De Klerk GJ (2003) Effect of low temperature on dormancy and growth after planting in lily bulblets regenerated in vitro. Plant Growth Regul 40:267-275

Le Nard M, Fiala V (1990) Post-harvest variation of free arginine in basal plate tissues of tulip bulbs; relation to bulb physiological evolution. Acta Hort 266:293-298

Mader JC (1995) Polyamines in Solanum tuberosum in vitro: free and conjugated polyamines in hormone-induced tuberisation. J Plant Physiol 146:115-120

Murashige T, Skoog F (1962) A revised medium for rapid assays with tobacco tissue cultures. Physiol Plant 15:473-497

Nojiri H, Yamane H, Seto H, Yamaguchi I, Murofushi N, Yoshihara T, Shibaoka H (1992) Qualitative and quantitative analysis of endogenous jasmonic acid in bulbing and non-bulbing onion plants. Plant Cell Physiol 33:1225-1231

Ondo Ovono P, Kevers C, Dommes J (2010a) Tuber formation and development of Dioscorea cayenensis-Dioscorea rotundata complex in vitro effect of polyamines. In Vitro Cel Dev Biol Plant 46:81-88

Ondo Ovono P, Kevers C, Dommes J (2010b) Tuber formation and growth of Dioscorea cayenensis-D. rotundata complex: interactions between exogenous and endogenous jasmonic acid and polyamines. Plant Growth Regul 60:247-253

Podwyszyńska M (2006a) Effect of ethylene, auxin and methyl jasmonate on bulb formation in vitro in tulip shoot cultures. Adv Agric Sci Problem Issues 510:461-469

Podwyszyńska M (2006b) Improvement of bulb formation in micropropagated tulips by treatment with NAA and paclobutrazol or ancymidol. Acta Hort 725:679-684

Podwyszyńska M (2012) The mechanisms of in vitro storage organ formation in ornamental geophytes. Flor Ornament Biotechnol. Glob Sci Books 6:9-23

Podwyszyńska M, Sochacki D (2010) Micropropagation of tulip: production of virus-free stock plants. In: Jain SM, Ochatt SJ (eds) Protocols for in vitro propagation of ornamental plants, methods in molecular biology (Springer protocols) 589. Humana Press/Springer, New York, pp 243-256

Podwyszyńska M, Michalczuk L, Miszczak A (2004) Content of endogenous abscisic acid in tulip shoots cultured in vitro depending on micropropagation stage and genotype. In: Abstracts of IX international symposium on flower bulbs, Niigata, Japan, 19-22, April, 2004, 122 pp

Podwyszyńska M, Novák O, Doležal K, Strnad M (2014) Endogenous cytokinin dynamics in micropropagated tulips during bulb formation process influenced by TDZ and iP pre-treatment. Plant Cell Tissue Organ Cult 119:331-346

Rakova NY, Romanov GA (2005) Polyamines suppress manifestation of cytokinin primary effects. Russ J Plant Physiol 52:50-57

Ravnikar M, Žel J, Plaper I, Špacapan A (1993) Jasmonic acid stimulates shoot and bulb formation of garlic in vitro. J Plant Growth Regul 12:73-77

Rees AR (1992) Ornamental bulbs, corms and tubers. CAB International, Oxon

Santos I, Salema R (2000) Promotion by jasmonic acid of bulb formation in shoot cultures of Narcissus triandrus L. Plant Growth Regul 30:133-138

Sergiev IG, Alexieva VS, Karanov EN (1995) Cytokinin and anticytokinin effects on growth and free polyamine content in etiolated and green radish cotyledons. J Plant Physiol 145: 266-270

Steiner N, Santa-Catarina C, Silveira V, Floh EI, Guerra MP (2007) Polyamine effects on growth and endogenous hormones levels in Araucaria angustifolia embryogenic cultures. Plant Cell Tissue Organ Cult 89:55-62

Tanimoto S, Matsubara Y (1995) Stimulating effect of spermine on bulblet formation in bulb-scale segments of Lilium longiflorum. Plant Cell Rep 15:297-300

Tavladoraki P, Cona A, Federico R, Tempera G, Viceconte N, Saccoccio S, Battaglia V, Toninello A, Agostinelli E (2012) Polyamine catabolism: target for anti-proliferative therapies in animals and stress tolerance strategies in plants. Amino Acids 42:411-426

Varshney A, Dhawan V, Srivastava PS (2000) Synergistic effect of polyamines on bulblet multiplication in Lillum sp. (Asiatic Hybrids). J Plant Biochem Biotechnol 9:115-118

Vreughdenhil D, Xu X, Jung CS, Van Lammeren AAM, Ewing EE (1999) Initial anatomical changes associated with tuber formation on single node potato (Solanum tuberosum L.) cuttings: a reevaluation. Ann Bot 84:675-680

Walters D, Cowley T, Mitchell A (2002) Methyl jasmonate alters polyamine metabolism and induces systemic protection against powdery mildew infection in barley seedlings. J Exp Bot 53: $747-756$

Yamazaki H, Nishijima T, Koshioka M, Miura H (2002) Gibberellins do not act against abscisic acid in the regulation of bulb dormancy of Allium wakegi Araki. Plant Growth Regul 36: 223-229

Zaffryar S, Zimerman B, Abu-Abied M, Belausov E, Lurya G, Vainstein A, Kamenetsky R, Sadot E (2007) Developmentspecific association of amyloplasts with microtubules in scale cell of Narcissus tazetta. Protoplasma 230:153-163 